\section{The Rich and the Poor: Demographics of the U.S. Wealth Distribution}

\section{John C. Weicher}

rowing concern about economic inequality has created widespread interest in the distribution and concentration of wealth in the United States. Wealth is much more concentrated than income. The wealthiest 1 percent of U.S. households own about one-third of total household net worth, while the top 1 percent of the income distribution receives about 10 percent of total income. At the other end, a few percent of households have negative net worth, and the poorest 20 percent have no net worth as a whole.

This paper describes the demographic attributes of both rich and poor households, and also the composition of their holdings. The data are drawn from surveys of household wealth conducted for the Federal Reserve Board in 1983, 1989, and 1992, years which approximate to the turning points of the 1982-91 business cycle.

Weal th is measured as the value of assets minus the value of liabilities, both defined broadly. In my experience, financial assets, particularly stocks, come first to mind when "wealth" is mentioned, among both economists and laymen, but wealth also includes the value of unincorporated business and investment real estate (rental housing and commercial buildings), and the value of owneroccupied homes, and automobiles. Table
1 reports the components of wealth, or net worth, as it is defined in this study.

There are large demographic differences between rich and poor. The richest 1 percent are middle-aged and old; they are married; and they are well educated. N early all are white, although there are problems with the racial and ethnic classifications. Households in the poorest 20 percent are generally young; about twothirds are single individuals; more than one-third have not finished high school. Only about half are white; minorities are substantially overrepresented (subject to the same qualification). The characteristics of the extremes are consistent with the broad pattern of wealth holdings among U.S. households. The typical household starts with little wealth and accumulates it during the working years, then draws it down to some extent after retirement. These findings are not surprising, and they do not change greatly from one survey to the next.

What is surprising is the composition of asset holdings among the rich. Most of their weal th is in the form of unincorporated business or investment real estate. They are owners of small businesses or professional practices. Stocks, bonds, and other financial assets represent less than one-third of their assets. This pattern strikingly demonstrates the importance of a broad definition of wealth.

A nother surprising finding is that the rich do not appear to be the same people over time, at least to a substantial extent. This statement must be taken cautiously, because the surveys are not longitudinal. They do identify the types of businesses owned. These fluctuate sharply from one survey to the next, suggesting that different individuals were in the top 1 percent at different dates. It is probably also true that those at the bottom of the distribution are not the same people either, judging from the small changes in the age distribution between surveys, but this result is less sur- 


\section{Table 1}

\section{Definition of Wealth (Net Worth)}

\begin{tabular}{|c|c|}
\hline Assets & Liabilities \\
\hline Value of Home & Mortgages/ Home Equity Loans \\
\hline \multirow[t]{3}{*}{ Value of Cars } & Auto Loans \\
\hline & Consumer Debt \\
\hline & Other Debt \\
\hline Investment Real Estate* & Mortgages on Property \\
\hline Unincorporated Business** & Debts of Business \\
\hline Stocks & \\
\hline Bonds & \\
\hline Mutual Funds & \\
\hline Trusts & \\
\hline Checking Accounts & \\
\hline Savings Accounts & \\
\hline Money Market Funds & \\
\hline IRAs/ Keoghs & \\
\hline Life Insurance (Cash Value) & \\
\hline Thrift-Type Pensions (Current Value) & \\
\hline Miscellaneous Assets & \\
\hline
\end{tabular}

${ }^{1}$ For more extensive descriptions of these surveys, see Avery and others (1984), Avery and Elliehausen (1986), Avery, Elliehausen, and Kennickell (1988), Kennickell and ShackMarquez (1992), Kennickell and Starr-McCluer (1994), and Weicher (1995)

2 Readers of my previous articles (Weicher, 1995; Weicher, 1997) may find it useful to know that the weights used in these tables are B3016 for $1983, \times 40125$ for 1989 , and X42000 in 1992. The choice of weights for 1983 and 1989 does not affect the results to any important extent. prising. The same sorts of people are rich-and poor-over time, but apparently not the same individuals.

\section{THE SURVEY OF CONSUMER FINANCES}

The data source for this article is the Federal Reserve Board's Survey of Consumer Finances (SCF). The SCF is one of the few surveys reporting assets and liabilities of individual households for a sample of the entire population on a consistent basis over time. Three surveys were conducted at about the turning points of the 1982-91 business cycle. The first cyclical trough was N ovember 1982; the 1983 SCF was conducted between February and August 1983, and half the interviews were conducted by April. The peak occurred in July 1990; the 1989 SCF was conducted between August 1989 and March 1990. The next trough occurred in March 1991; the 1992 SCF was conducted between June and November 1992.

An important feature of the SCF is that it includes a special sample of high-income households who are likely to have large wealth holdings, as well as a cross-section sample representing the entire population. Because wealth is concentrated, a random sample of households gives little information about a large fraction of household wealth. The high-income sample has grown in importance from one survey to the next, in an effort to give equal sampling probabilities to all dollars of wealth, rather than all households. ${ }^{1}$

\section{THE DEMOGRAPHIC COMPOSITION OF THE SCF}

Table 2 shows the proportion of the SCF households in each of the demographic categories reported in this article. It is a convenient benchmark for comparison with the composition of the rich and the poor. The table shows the importance of the post-war baby boom, and the declines in both marriages and births to married women in recent decades. ${ }^{2}$

In most cases, the weighted percentages in the SCF parallel the percentages in the population, as measured by the Census Bureau's annual Current Population Survey (CPS). There are some exceptions. The most important concerns the racial and ethnic categorization of households. In the 1983 SCF, race and ethnicity were determined by the interviewer without asking the respondent, while in 1989 and 1992 the respondent was asked to identify his or her own race, which is the standard Census Bu reau practice. The effect of this difference can be judged from Table 2. The CPS does not cross-classify Hispanic households by race, but those data are available in the decennial Censuses of 1980 and 1990 and are reported in the table for comparison with the SCF. It appears that interviewers counted more persons as black, and fewer as Hispanic or "other," compared to the respondents' self-identification. As a result, the SCF reports a large increase in Hispanic and "other" households between 1983 and 


\section{Table 2}

\section{Demographic Composition of Survey of Consumer Finances and Current Population Survey}

\begin{tabular}{|c|c|c|c|c|c|c|}
\hline \multirow[t]{2}{*}{ Category } & \multicolumn{2}{|c|}{1983} & \multicolumn{2}{|c|}{1989} & \multicolumn{2}{|c|}{1992} \\
\hline & SCF & CPS* & SCF & CPS* & SCF & CPS \\
\hline \multicolumn{7}{|l|}{ Age of household head: } \\
\hline Under 25 & $8.0 \%$ & $6.8 \%$ & $4.8 \%$ & $5.5 \%$ & $5.1 \%$ & $5.1 \%$ \\
\hline $25-34$ & 22.6 & 22.8 & 20.9 & 21.9 & 20.6 & 20.9 \\
\hline $35-44$ & 19.5 & 19.1 & 23.3 & 22.0 & 22.7 & 22.8 \\
\hline $45-54$ & 15.5 & 14.7 & 14.2 & 15.5 & 16.3 & 16.3 \\
\hline $55-64$ & 15.0 & 15.6 & 14.5 & 13.4 & 13.4 & 13.1 \\
\hline $65-74$ & 12.2 & 12.6 & 13.1 & 12.6 & 12.7 & 12.5 \\
\hline $75+$ & 7.2 & 8.4 & 9.2 & 9.0 & 9.3 & 9.3 \\
\hline Median age & 44 & 45 & 45 & 45 & 45 & 45 \\
\hline \multicolumn{7}{|l|}{ Household composition: } \\
\hline Married couple, no children & $29.4 \%$ & $30.4 \%$ & $29.8 \%$ & $29.8 \%$ & $30.0 \%$ & $29.3 \%$ \\
\hline Married couple, children & 31.2 & 29.0 & 28.6 & 26.3 & 27.4 & 25.5 \\
\hline Single male, no children & 12.0 & 12.9 & 12.8 & 14.3 & 14.0 & 14.8 \\
\hline Single male, children & 1.1 & 0.9 & 0.4 & 1.2 & 1.0 & 1.3 \\
\hline Single female, no children & 18.1 & 20.0 & 21.8 & 21.4 & 20.8 & 21.7 \\
\hline Single female, children & 8.2 & 6.8 & 6.7 & 7.1 & 6.8 & 7.4 \\
\hline \multicolumn{7}{|l|}{ Race/ ethnicity: } \\
\hline White & $82.3 \%$ & $82.8 \% *$ & $75.4 \%$ & $80.2 \% *$ & $75.1 \%$ & $\mathrm{~N} / \mathrm{A}$ \\
\hline Black & 12.9 & $10.3^{*}$ & 12.6 & $10.6^{*}$ & 12.7 & $\mathrm{~N} / \mathrm{A}$ \\
\hline Hispanic* & 3.7 & $5.0^{*}$ & 7.7 & $6.4^{*}$ & 7.6 & $\mathrm{~N} / \mathrm{A}$ \\
\hline Other** & 1.1 & $1.9 *$ & 4.3 & $2.8^{*}$ & 4.6 & $\mathrm{~N} / \mathrm{A}$ \\
\hline \multicolumn{7}{|c|}{$\begin{array}{l}\text { * Hispanic Americans are counted separately from other groups in the SCF but included as members of racial groups, as well as } \\
\text { Hispanics, in the CPS. The decennial Census cross-classifies race and ethniaty, and has been used to construct similar measures to the } \\
\text { SCF. These measures, based on the } 1980 \text { and } 1990 \text { Censuses, are reported in the CPS columns for } 1983 \text { and 1989, respectively. }\end{array}$} \\
\hline $\begin{array}{l}\text { **Includes Asians and Pacific Is } \\
\text { (about } 20 \text { percent). }\end{array}$ & perc & $1983 \mathrm{SC}$ & 0 and & Census & can In & laska natives \\
\hline
\end{tabular}

1989, a shift that is not evident in either the decennial Census or the CPS. The later SCF surveys also report fewer white households, and more members of all minority groups, than did the 1990 Census.

The SCF also differs from the CPS in its reported household composition. Most importantly, it reports a decline in the incidence of single women with children, in contrast to the slight increase reported in the
CPS. The SCF and CPS data differ primarily for 1983. In addition, the SCF shows a sharp fluctuation over the cycle in the number of single men with children, a finding which is not corroborated by the CPS. This difference may occur because the sample size for this small category also fluctuatesfrom 40 in 1983 to 17 in 1989 to 37 in 1992 - and the weights do not compensate for the fluctuation. 
Table 3

\section{Demographic Characteristics of the Richest 1 Percent of U.S. Households}

\begin{tabular}{|c|c|c|c|}
\hline & 1983 & 1989 & 1992 \\
\hline \multicolumn{4}{|l|}{ Age of household head: } \\
\hline Under 25 & $0.0 \%$ & $0.0 \%$ & $0.0 \%$ \\
\hline $25-34$ & 2.1 & 1.3 & 2.1 \\
\hline $35-44$ & 8.4 & 15.5 & 10.2 \\
\hline $45-54$ & 27.9 & 27.0 & 26.0 \\
\hline $55-64$ & 30.3 & 22.2 & 26.4 \\
\hline $65-74$ & 20.9 & 22.1 & 24.7 \\
\hline $75+$ & 10.4 & 11.9 & 10.6 \\
\hline Median age: & 58 & 57 & 59 \\
\hline \multicolumn{4}{|l|}{ Household composition: } \\
\hline Married, no children at home & $66.2 \%$ & $59.6 \%$ & $63.8 \%$ \\
\hline Married, children at home & 23.3 & 25.4 & 18.6 \\
\hline Single male, no children & 4.0 & 8.5 & 9.1 \\
\hline Single male, children & 0.1 & 2.5 & 0.3 \\
\hline Single female, no children & 6.4 & 3.5 & 8.2 \\
\hline Single female, children & 0.0 & 0.7 & 0.0 \\
\hline Married, ever had children & $83.9 \%$ & $80.5 \%$ & $71.7 \%$ \\
\hline Married, never had children & 5.6 & 4.5 & 10.7 \\
\hline Widowed & 1.9 & 3.2 & 6.6 \\
\hline Widower & 1.7 & 1.0 & 2.8 \\
\hline Divorced & 5.3 & 10.2 & 5.3 \\
\hline Never married & 1.7 & 0.8 & 2.9 \\
\hline \multicolumn{4}{|l|}{ Race/ Ethnicity of household head: } \\
\hline White & N.C. & $94.5 \%$ & $91.2 \%$ \\
\hline Black & N.C. & 0.7 & 0.2 \\
\hline Hispanic & N.C. & 1.1 & 1.6 \\
\hline Other & N.C. & 3.7 & 7.0 \\
\hline \multicolumn{4}{|l|}{ Education of household head: } \\
\hline Grade school & $1.3 \%$ & $2.8 \%$ & $0.3 \%$ \\
\hline Some high school & 1.5 & 1.3 & 1.4 \\
\hline High school graduate & 14.1 & 8.8 & 9.4 \\
\hline Some college & 20.3 & 14.0 & 19.4 \\
\hline College graduate or more & 62.8 & 73.2 & 69.5 \\
\hline
\end{tabular}

N.C.: Not calculated because of inconsistency with identification procedures used in later surveys.

These differences affect the apparent patterns of wealth by demographic category, as will be discussed later.

\section{WHO ARE THE RICH?}

The ownership of wealth is much more concentrated than other measures of economic well-being. This section reports the attributes of the richest 1 percent of households, who hold approximately onethird of all household wealth. The threshold for inclusion is about $\$ 1.9$ million in net worth in $1983, \$ 2.2$ million in 1989 , and $\$ 2.4$ million in 1992 (all measured in 1992 dollars). This definition of "rich" has been used in a number of studies. $^{3}$

\section{Household Characteristics}

Table 3 shows the demographic characteristics of these rich households. They are basically similar at each date. Most heads of households in this group are middle-aged or elderly. Married couples predominate; fewer than 5 percent were never married. The age distribution is reflected in the fact that a large majority have had children, but a minority now have children living at home. Married couples in which the head is under age 45 typically have children living at home; those in which the head is 55 or older typically do not; in the 45-54 age group, about one-half have children at home and one-half do not. Most rich households are headed by college graduates.

There are some changes over the cycle. The proportion of relatively young households (with heads under 45) increased from 1983 to 1989 and then declined during the recession. The proportion of married couples declined from about 90 percent to 82 percent over the cycle; married couples with children accounted for the larger part of this decrease. The proportion with white heads of household declined and the proportion in the "other" category increased, but the changes from 1983 to 1989 should not be given much credence because of the difference between the surveys.

Comparison with Table 2 shows that the households in the richest 1 percent are much better educated and quite a bit older than the general population. They are dis- 
proportionately white. They are more likely to be married but, because of their age, less likely to have children living at home. However, the precision of the percentages in Table 3 should not be overemphasized. The number of observations in the top 1 percent of each survey is not large to begin with, especially in 1983: 287 in 1983, 456 in 1989, and 644 in 1992. Thus there are not many respondents in some of the smaller demographic categories. Where there are marked differences among the surveys in the samples and weighted proportions for the smaller categories, as shown in Table 2, the representation of these categories among the top 1 percent varies as well, and the proportions in Table 3 may be suspect.

\section{Assets Held by the Rich}

Table 4 describes the components of net worth for the richest 1 percent. As the top panel shows, unincorporated business consistently constituted the largest share of their wealth and grew in importance from about one-third in 1983 to over 40 percent by 1992. Commercial and rental property accounted for about one-sixth in 1983, rising to one-fifth in 1992. ${ }^{4}$ The most surprising finding is the sharp decline in the importance of stock ownership from 1983 to 1989, despite the stock market boom of the 1980s.

Unincorporated business, investment real estate, and farms may be considered "entrepreneurial assets" because their owners are probably active managers, as well as bearers of the risk of loss. In contrast, owners of financial assets are typically not active in the management of the enterprises that issue the assets and therefore cannot affect the value of the asset by their own efforts.

The second panel shows the importance of the different assets to individual households: What was the most important asset in the portfolio of each rich household? The two panels show similar patterns. Unincorporated business was again the most important, although the proportion fluctuated over the cycle. Financial

\section{Table 4}

\section{Asset Holdings of the Richest 1 Percent of Households}

\begin{tabular}{|c|c|c|c|}
\hline & 1983 & 1989 & 1992 \\
\hline Unincorporated business & $33.8 \%$ & $39.7 \%$ & $43.2 \%$ \\
\hline Stocks & 18.2 & 7.7 & 10.9 \\
\hline Investment real estate & 16.7 & 16.5 & 19.4 \\
\hline Home equity & 8.6 & 8.1 & 7.0 \\
\hline Trusts & 6.4 & 3.8 & 2.1 \\
\hline Bonds & 5.9 & 5.7 & 5.0 \\
\hline Farms & 2.7 & 2.6 & 1.5 \\
\hline Miscellaneous assets & 1.0 & 5.9 & 2.8 \\
\hline All other & 6.1 & 10.0 & 8.4 \\
\hline
\end{tabular}

Proportion of households for whom asset category constitutes largest share of net worth

\begin{tabular}{|c|c|c|c|}
\hline & 1983 & 1989 & 1992 \\
\hline Unincorporated business & $41.4 \%$ & $33.6 \%$ & $43.5 \%$ \\
\hline Financial Assets* & 29.4 & 24.2 & 23.8 \\
\hline Investment real estate & 17.6 & 20.1 & 19.4 \\
\hline Farms & 7.0 & 3.1 & 1.8 \\
\hline Miscellaneous & 0.0 & 8.6 & 0.8 \\
\hline All other & 4.6 & 10.2 & 10.7 \\
\hline
\end{tabular}

assets declined in importance after 1983, largely because of the decline in stock holdings. Farms also declined in importance. Investment real estate was the most important asset for about one-fifth of the richest households in each year.

These patterns vary according to the age of the household head. In general, financial assets are more important and unincorporated business is less important for older households. In 1983, financial assets were the largest component of net worth for the age cohorts of households with head aged 65 and older, but not for any younger cohort. In 1989 and 1992, financial assets were the largest holding only for the cohort with head aged 75 or older. At the other end of the age distribution, if young households did manage to qualify for inclusion among the very rich, they did it as owners of real estate or unincorporated businesses.
3 For example, Weicher (1995, 1997) and Wolff (1995 and most of the studies cited therein).

4 The 1991 Residential Finance Survey, conducted by the Census Bureau in conjunction with the decennial Census of Population, reports that 92 percent of residential rental properties are owned by individual investors, and another 4 percent are owned by partnerships or other entities whose holdings are included in "investment real estate" in the SCF. Most of these properties are small, with one to four rental units, but even in the largest size category (50 or more units) over 75 percent are owned by individuals or partnerships. 
M ost of the rich are entrepreneurs, and most have earned their wealth. Inheritance accounts for about 8 percent of the net worth of these households in the aggregate. More than half have never inherited anything, and inherited wealth is less than 10 percent of total wealth for more than two-thirds of those who have.

\section{Miscellaneous Assets}

Miscellaneous assets were the most important holding for a remarkably large number of wealthy households in 1989. This apparently results, in part, from a change in the questionnaire. The category includes 23 types of assets in 1983, 30 in 1989 , and 32 in 1992. It is very heterogenous. In all three years it included many collectibles such as coins, stamps, Oriental rugs, and objets d'art; oil and gas leases; various debts owed to the household; and much more. Ten new categories were listed in 1989 and two more in 1992. Among the additional 1989 categories were future proceeds from a lawsuit or an estate, deferred compensation, and "other." The most commonly reported miscellaneous asset in 1983-boats- was moved to the "vehicle" category in 1989, along with campers, airplanes, and motorcycles. Vehicles are not a large share of the wealth of any rich households.

Looking at the individual observations helps to explain the changes in miscellaneous assets. Not many wealthy households reported assets in the additional categories in 1989, but some of those who did reported large holdings. One household reported \$28 million worth of "other" assets. Seven others reported more than $\$ 1$ million of "other," future proceeds, or deferred compensation. One of these seven, presumably from the cross-section sample, had a weight large enough to represent about 4.5 percent of the richest households, and thus by itself to account for about half of the households for whom miscellaneous assets were the largest holding. Two others accounted for about 1.5 percent more, combined. In 1992, more households reported holdings in the categories added in 1989, but fewer reported extremely large holdings, and none had such large weights.

When the observations are weighted, the proportion of wealthy households reporting miscellaneous assets doubled between 1983 and 1989, from 33 percent to 68 percent, then declined to 56 percent in 1992. These changes were paralleled among all households: 11 percent in 1983, 22 percent in 1989, and 18 percent in 1992. The mean value of miscellaneous assets for weal thy households increased from $\$ 168,000$ in 1983 to $\$ 615,000$ in 1989 , and then declined to $\$ 320,000$ in 1992.

\section{Unincorporated Business}

Given the importance of unincorporated business among the richest households, it is worth taking a brief look at the kinds of businesses they own. The SCF asks about the type of business, for those in which the household has a management interest. In general, there is not a very close correspondence among the kinds of businesses owned from one survey to the next. In 1983, the most common classification was "professional practice," including law, medicine, accounting and architecture specifically, and perhaps others as well. Some 22 percent of the richest households owning unincorporated businesses were in this category. The second most common classification, at 20 percent, was "other wholesale/retail outlets," including everything except food and liquor, restaurants, gas stations, and direct sales. In 1989 and 1992, real estate and insurance was the most common, at 43 percent in 1989 and 27 percent in 1992. Few of the richest households were in these lines of business in 1983. "Other outlets" was again the second most common category, at 26 percent, in 1989 , while manufacturing was the second most common in 1992, at 15 percent. $^{5}$

Taken at face value, these data suggest that different households were in the top 1 percent in different years. The shifts in portfolio composition support 


\section{HOUSEHOLD EQUITY AND WEALTH}

Laymen often object to the inclusion of home equity in household wealth. They argue that the household must have a place to live, and if it sells one house, it must buy another, of about the same quality in about the same kind of neighborhood. This argument overlooks the fact that most homeowners finance their purchase with a mortgage. An increase in the value of the home accrues entirely to the benefit of the owner. Consider, for instance, a family with a $\$ 100,000$ income, a home worth $\$ 200,000$, and a mortgage of $\$ 150,000$. If all prices double, the family has a $\$ 200,000$ income, a home worth $\$ 400,000$, but still a mortgage of $\$ 150,000$. The family's home equity has increased fivefold, from $\$ 50,000$ to $\$ 250,000$. The homeowner can now afford a home worth $\$ 550,000$, using its $\$ 250,000$ equity as a down payment and making the monthly payments on a $\$ 300,000$ mortgage out of its $\$ 200,000$ income. It also has other options. It can realize the gain by refinancing the mortgage and converting the gain to cash, or by selling the house and becoming a renter. the same inference. The samples are small, however, and the differences may reflect sampling variability as much as real change.

\section{O mitted Assets}

The SCF data is very detailed, but not exhaustive. Several types of assets are not reported. The most important omissions are the present value of private pensions and Social Security benefits that the household expects to receive in the future, and the value of most consumer durables. The debt incurred to buy the durable is reported, but not its value. Automobiles and other vehicles are exceptions; both value and debt are reported. If the omitted assets were included, it is clear that the distribution would be less concentrated. ${ }^{6}$

\section{Alternative Definitions of "Rich"}

Any definition of "rich" is essentially arbitrary. The richest 1 percent is frequently used by analysts, but other concepts are also used. To see whether the results are sensitive to the choice of definition, this section reports data for two more inclusive al ternatives: net worth of $\$ 1$ million, and households in the richest decile. The incidence of millionaires was 2.4 percent in 1983, 2.5 percent in 1989, and 3.2 percent in 1992.

The demographics of these groupings are very similar in all three years. The only difference worth noting is that education is positively correlated with wealth, even for these small groups. Particularly in 1983 and 1989, the narrower the group, the higher the proportion of college graduates. In 1992, the incidence was the same for the richest 1 percent and for millionaires, and the difference between the richest 1 percent and the richest decile narrowed from about 20 percent to about 10 percent.

The pattern of asset holdings does vary with the criterion. Asset data for the additional groups are shown in Table 5, in the same format as the data for the richest 1 percent in Table 4. The more inclusive the definition of "rich," the less important are entrepreneurial assets and entrepreneurship. In 1983, for example, entrepreneurial assets account for 53.2 percent of the wealth of the richest 1 percent, 52.0 percent among millionaires, and 47.5 percent among the richest decile. Similarly, 66 percent of the richest 1 percent were entrepreneurs in 1983, compared to 59 percent of millionaires and 51 percent of the richest decile.

Conversely, home equity increases in importance as the definition is broadened.

\footnotetext{
${ }^{6}$ Omitted assets are discussed in detail in Weicher (1997).
} 


\section{Table 5}

\section{Asset Holdings of "The Rich": Other Definitions}

Relative importance of individual asset categories

\begin{tabular}{|c|c|c|c|c|c|c|}
\hline & \multicolumn{3}{|c|}{ Millionaires } & \multicolumn{3}{|c|}{ Top Decile } \\
\hline & 1983 & 1989 & 1992 & 1983 & 1989 & 1992 \\
\hline Unincorporated business & $30.5 \%$ & $34.1 \%$ & $36.0 \%$ & $24.7 \%$ & $27.1 \%$ & $29.7 \%$ \\
\hline Stocks & 16.9 & 7.9 & 10.8 & 13.8 & 7.7 & 10.4 \\
\hline Investment real estate & 16.4 & 16.5 & 17.9 & 16.9 & 15.8 & 17.0 \\
\hline Home equity & 10.6 & 11.5 & 10.6 & 16.4 & 16.8 & 15.0 \\
\hline Trusts & 5.8 & 3.1 & 2.4 & 4.2 & 3.0 & 2.2 \\
\hline Bonds & 5.9 & 5.4 & 5.0 & 5.3 & 4.9 & 4.6 \\
\hline Farms & 5.1 & 3.1 & 2.7 & 5.9 & 3.3 & 2.0 \\
\hline Miscellaneous assets & 1.2 & 5.4 & 3.0 & 1.5 & 5.3 & 2.7 \\
\hline All other & 7.6 & 13.0 & 11.6 & 11.3 & 16.1 & 16.4 \\
\hline
\end{tabular}

Proportion of households for whom the specific asset category constitutes the largest share of net w orth

\begin{tabular}{|c|c|c|c|c|c|c|}
\hline & 1983 & 1989 & 1992 & 1983 & 1989 & 1992 \\
\hline Unincorporated business & $31.0 \%$ & $27.0 \%$ & $32.3 \%$ & $19.2 \%$ & $18.1 \%$ & $21.9 \%$ \\
\hline Financial assets* & 30.7 & 18.0 & 23.1 & 17.9 & 18.1 & 19.5 \\
\hline Investment real estate & 16.0 & 19.4 & 17.3 & 21.3 & 16.8 & 16.4 \\
\hline Farms & 11.8 & 5.0 & 4.9 & 10.1 & 4.4 & 2.4 \\
\hline Miscellaneous & 0.3 & 4.9 & 3.1 & 0.8 & 2.7 & 1.5 \\
\hline All other & 10.2 & 25.7 & 19.3 & 30.7 & 39.9 & 38.3 \\
\hline Owner-occupied home & 4.3 & 15.3 & 7.7 & 22.4 & 28.0 & 22.3 \\
\hline
\end{tabular}

* Total of stocks, bonds, trusts

It is particularly important in the richest decile because the threshold is low: $\$ 220,000$ in $1983, \$ 344,000$ in 1989 , and $\$ 360,000$ in 1992 . Homeowners who bought their first home before the inflation of the late 1960s and 1970s may have enjoyed enough appreciation by the 1980 s and 1990s to qualify as "rich" by this criterion, even if they do not have much else.

A second pattern is that entrepreneurial assets (though not entrepreneurship) have become more important over time for the two more restrictive definitions, particularly the top 1 percent. There are also some differences in financial asset holdings, with fewer coupon clippers over time among the richest 1 percent, but slightly more among the richest decile.
The combined effect of these patterns is that differences by the definition of "rich" have become more pronounced over time. The differences are quantitative rather than qualitative, however. By every definition in every year, unincorporated business is the most important asset for more rich households, and more of the rich are entrepreneurs. Even by the broadest definition, more are business men and women than holders of financial assets. ${ }^{7}$

\section{WHO ARE THE POOR?}

There is no generally accepted standard for "wealth poverty" (unlike the "poverty line" for income). The bottom 20 percent, with a combined net worth of about zero in each year, may be an appro- 
priate group to represent the opposite end of the spectrum. In the remainder of this paper, this group will be identified as "the poor." Most of these households do have a positive net worth, but a minor fraction have negative net worth, and the absolute value of their negative net worth is higher, on average, than the positive net worth of the other poor households. Households with negative net worth account for about 25 percent of the group in 1983 and 1992, and about 38 percent in 1989- 5 to 8 percent of all households.

\section{Household Characteristics}

Table 6 contains demographic information for these poor households that is similar to the information in Table 3 for the richest 1 percent of households. The samples consist of 736 households in 1983, 410 in 1989, and 586 in 1992. They are similar in size to the samples for the richest 1 percent in the later surveys, but much larger than the 1983 sample.

In many respects besides wealth, the poor are al most the opposite of the rich. They are much younger, and they have had much less education; 35 to 40 percent have not finished high school. Compared to the total population as shown in Table 2, these poor households are substantially younger.

Fewer are married, but more have children. The incidence of single women with children among the poor households is more than double the incidence of such households in the general population. The incidence of minorities is also disproportionately large. These patterns appear to be generally stable over time; perhaps the most notable and surprising change was a modest increase in the proportion of poor household heads who were white during the 1989-92 recessionary period, and a corresponding decline in the proportion who were black.

The median age of these households rose slightly over time, but only by a few months for each passing year-a finding which suggests that the same households are probably not poor from one survey to the next. This is not surprising; as the

\section{Table 6}

\section{Demographic Characteristics of the Poorest Households \\ (Bottom 20 percent)}

\begin{tabular}{|c|c|c|c|}
\hline & 1983 & 1989 & 1992 \\
\hline \multicolumn{4}{|l|}{ Age of household head: } \\
\hline Under 25 & $20.9 \%$ & $12.6 \%$ & $13.8 \%$ \\
\hline $25-34$ & 33.0 & 36.7 & 33.0 \\
\hline $35-44$ & 14.9 & 22.9 & 21.6 \\
\hline $45-54$ & 9.6 & 6.9 & 11.3 \\
\hline $55-64$ & 9.1 & 8.8 & 7.0 \\
\hline $65-74$ & 5.6 & 7.1 & 8.4 \\
\hline $75+$ & 6.8 & 5.1 & 5.0 \\
\hline Median age: & 32 & 35 & 35 \\
\hline \multicolumn{4}{|l|}{ Household composition: } \\
\hline Married couple, no children & $11.0 \%$ & $9.6 \%$ & $13.5 \%$ \\
\hline Married couple, children & 23.2 & 22.3 & 22.2 \\
\hline Single male, no children & 21.3 & 20.6 & 18.1 \\
\hline Single male, children & 1.4 & 0.2 & 2.1 \\
\hline Single female, no children & 23.3 & 29.1 & 25.1 \\
\hline Single female, children & 19.8 & 18.2 & 19.0 \\
\hline \multicolumn{4}{|c|}{ Race/ ethnicity of household head: } \\
\hline White & N.C. & $48.8 \%$ & $55.9 \%$ \\
\hline Black & N.C. & 29.0 & 23.4 \\
\hline Hispanic & N.C. & 17.0 & 17.1 \\
\hline Other & N.C. & 5.2 & 3.6 \\
\hline \multicolumn{4}{|l|}{ Education of household head: } \\
\hline Grade school & $19.2 \%$ & $16.8 \%$ & $15.3 \%$ \\
\hline Some high school & 19.5 & 17.9 & 20.4 \\
\hline High school graduate & 29.0 & 35.2 & 33.4 \\
\hline Some college & 19.5 & 18.5 & 17.5 \\
\hline College graduate or more & 12.7 & 11.5 & 13.4 \\
\hline
\end{tabular}

N.C.: Not calculated because of inconsistency with identification procedures used in later surveys.

next section will show, for all households, wealth typically increases rapidly with age, through middle age, and then continues to rise more slowly until retirement.

\section{Economic Circumstances}

Table 7 provides some economic information about these poor households.

They are generally at the bottom of the 


\section{Table 7}

\section{Economic Position of Poorest Households (Bottom 20 percent)}

\begin{tabular}{|c|c|c|c|}
\hline & 1983 & 1989 & 1992 \\
\hline \multicolumn{4}{|l|}{ Income: } \\
\hline Less than $\$ 5,000$ & $11.0 \%$ & $21.1 \%$ & $15.8 \%$ \\
\hline$\$ 5,000$ to $\$ 9,999$ & 27.8 & 24.7 & 31.9 \\
\hline$\$ 10,000$ to $\$ 14,999$ & 19.6 & 21.5 & 15.8 \\
\hline$\$ 15,000$ to $\$ 19,999$ & 13.1 & 5.6 & 11.9 \\
\hline$\$ 20,000$ to $\$ 24,999$ & 9.9 & 8.3 & 9.0 \\
\hline$\$ 25,000$ or more & 18.5 & 18.7 & 15.6 \\
\hline Median & $\$ 13,000$ & $\$ 10,200$ & $\$ 11,000$ \\
\hline \multicolumn{4}{|c|}{ Labor Force Participation: } \\
\hline Working, full time & $48.4 \%$ & $53.4 \%$ & $53.6 \%$ \\
\hline Working, part time & 5.9 & 3.7 & 2.3 \\
\hline Unemployed & 16.0 & 12.1 & 11.9 \\
\hline Not in labor force & 29.7 & 30.8 & 31.8 \\
\hline \multicolumn{4}{|l|}{ Housing Tenure: } \\
\hline Owner & $4.7 \%$ & $6.3 \%$ & $7.8 \%$ \\
\hline Renter & 95.3 & 93.7 & 92.2 \\
\hline \multicolumn{4}{|l|}{ Net Worth: } \\
\hline Positive & $74.4 \%$ & $63.5 \%$ & $76.0 \%$ \\
\hline Negative & 25.6 & 36.5 & 24.0 \\
\hline Maximum & $\$ 3,800$ & $\$ 2,500$ & $\$ 4,500$ \\
\hline Median & $\$ 500$ & $\$ 0$ & $\$ 400$ \\
\hline \multicolumn{4}{|l|}{ Assets: } \\
\hline Less than $\$ 5,000$ & $81.1 \%$ & $78.6 \%$ & $79.5 \%$ \\
\hline$\$ 5,000$ to $\$ 9,999$ & 10.4 & 9.4 & 8.8 \\
\hline$\$ 10,000$ to $\$ 14,999$ & 2.8 & 5.6 & 4.5 \\
\hline$\$ 15,000$ or more & 5.6 & 6.3 & 7.3 \\
\hline Median & $\$ 1,700$ & $\$ 1,200$ & $\$ 1,900$ \\
\hline \multicolumn{4}{|l|}{ Liabilities: } \\
\hline Less than $\$ 5,000$ & $80.4 \%$ & $72.5 \%$ & $78.0 \%$ \\
\hline$\$ 5,000$ to $\$ 9,999$ & 9.0 & 9.3 & 7.4 \\
\hline$\$ 10,000$ to $\$ 14,999$ & 2.9 & 6.1 & 6.1 \\
\hline$\$ 15,000$ or more & 7.7 & 12.2 & 8.4 \\
\hline Median & $\$ 400$ & $\$ 600$ & $\$ 300$ \\
\hline
\end{tabular}

economic ladder in other respects besides wealth: About 40 percent had incomes below the poverty line in 1983, and about 45 percent in each of the later years (the income poverty line varies by household size). Well over 80 percent were in the lower half of the income distribution in all three surveys. It may be surprising that about half were working full-time; relatively few relied on welfare as a major source of income. Most had little in the way of either assets or liabilities.

\section{Households with Negative Net Worth}

Within the poorest 20 percent, distinct economic differences can be identified between households with positive and negative net worth. The former are apparently neither savers nor borrowers. Both their assets and their liabilities are typically smaller. More than half reported no debts at all. Their median net worth was $\$ 1,100$ in $1983, \$ 500$ in 1989 , and $\$ 1,000$ in 1992.

Paradoxically, the households with negative net worth appear to be in better economic circumstances, as shown in Table 8 (page 36). Their incomes as well as their assets are higher, more of them work, and in the later surveys more are homeowners. Their debts are not large, although it should be noted that the incidence of negative net worth rose during the years of economic growth and declined during the recessionary period. Consumer debt accounted for about 60 percent of their liabilities in 1983, and mortgage debt and auto loans for about 15 percent each. The debt data are distorted in the later years by one or two very large outliers for specific liabilities.

Typically, these households could achieve a positive wealth position by dedicating about 15 percent of one year's income to paying off debts, and they could pay off all their debts by devoting half a year's income to that purpose. Such actions certainly would not leave them very much to live on, but the calculations do suggest that the typical household is not in a hopeless position.

The households with negative net worth are also better educated than the other poor households. About 20 percent have a college degree, and only 25 percent 
have less than a high school diploma. For those with positive net worth, about 10 percent have graduated from college and about 50 percent did not graduate from high school. This finding suggests that some, at least, have negative net worth because they have recently finished college and owe money on student loans. Such households are not likely to be permanently poor. Their number is not large, however-between 4 and 12 percent of all households with negative net worth in the various surveys. In 1983 , the heads of nearly all of these households were under 35, but in the later years only about half were.

The demographic differences are less pronounced, but poor households with positive net worth were more often single and more often childless, especially in 1989, and the minority proportion was larger.

\section{WEALTH BY DEMOGRAPHIC CATEG ORY}

Besides the rich and the poor, another 79 percent of households fall somewhere in between. This section describes the wealth of all households- "rich," "poor," and "in between" combined, along various demographic dimensions. ${ }^{8}$ Table 9 (page 37) shows the median household wealth by demographic category for each year's survey.

As is true for the richest households, age is highly correlated with wealth. Households typically build wealth from a very low starting point during the years when their adult members are working and then draw it down in retirement. This pattern holds for all three surveys. Figure 1 reports the median wealth for households by one-year intervals, illustrating the wealth-age relationship. Because the sample sizes are small, the medians are calculated for a five-year moving average, centered on the year shown on the horizontal axis. Even then, there are noticeable fluctuations from year to year. The chart generally reflects a pattern of rising weal th during the economic expansion, and some loss of wealth during the recession. For most age groups, the median in 1983 is lower than the median for 1989 , and it is

\section{Figure 1}

\section{Median Net Worth by Age}

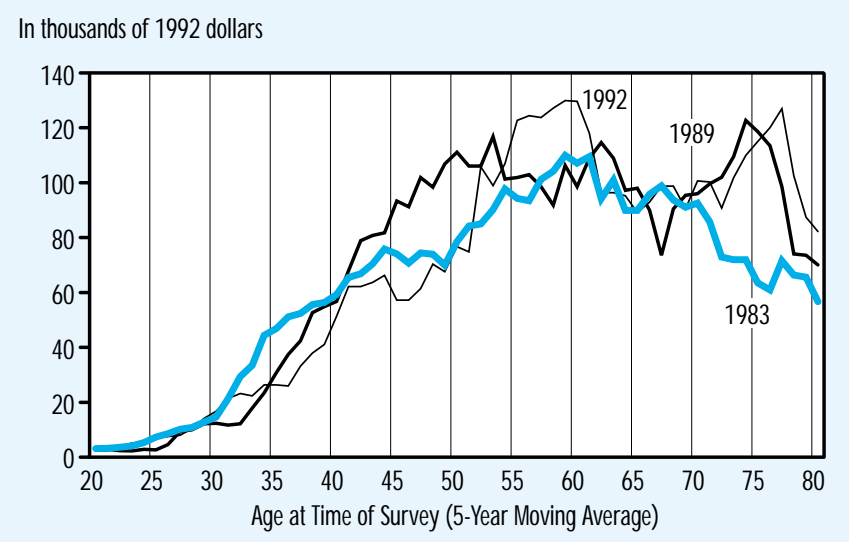

Figure 2

\section{Median Net Worth by Cohort Over Time}

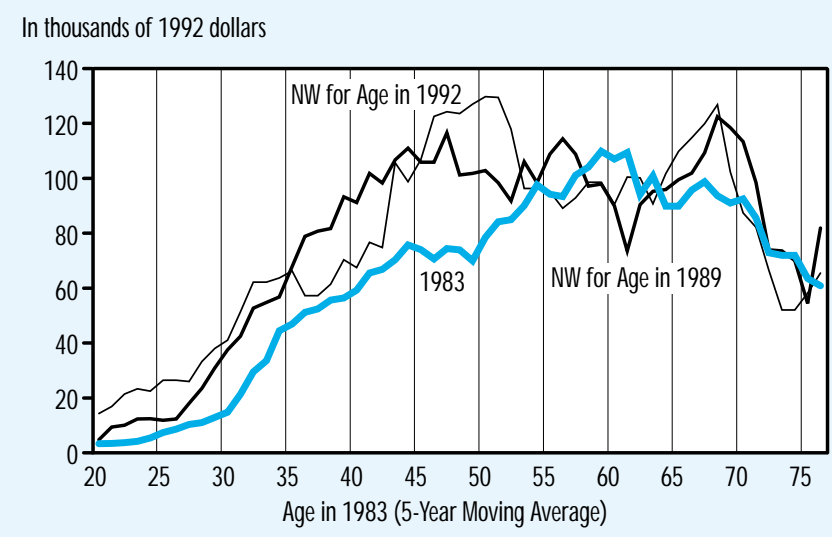

usually about the same or higher than the median for 1992.

Younger households are an exception, particularly those headed by persons in their 30s. Such households were better off in 1983 than those in the same age group were in 1989, after six years of economic growth. A possible explanation is the different inflation rates, and households' reactions to inflation. In the 1970 s, inflation was steadily if erratically accelerating, and young households bought homes as soon as possible as an inflation hedge. Once they were homeowners, they benefitted from the continuing unexpected increase in inflation. The home ownership rate for households with heads under age
8 Income is omitted from this discussion, because its relationship to wealth was analyzed in my previous papers (Weicher, 1995; Weicher, 1997). Wealth is highly correlated with income, more than with age or any other demographic attribute. 


\section{Table 8}

\section{Economic Position of Poorest Households (Households with Negative Worth)}

\begin{tabular}{|c|c|c|c|}
\hline & 1983 & 1989 & 1992 \\
\hline \multicolumn{4}{|l|}{ Income: } \\
\hline Less than $\$ 5,000$ & $11.7 \%$ & $14.0 \%$ & $11.7 \%$ \\
\hline$\$ 5,000$ to $\$ 9,999$ & 25.7 & 18.3 & 20.7 \\
\hline$\$ 10,000$ to $\$ 14,999$ & 16.8 & 22.7 & 16.4 \\
\hline$\$ 15,000$ to $\$ 19,999$ & 12.5 & 3.2 & 11.7 \\
\hline$\$ 20,000$ to $\$ 24,999$ & 11.9 & 13.9 & 11.6 \\
\hline$\$ 25,000$ or more & 21.3 & 27.8 & 27.9 \\
\hline Median & $\$ 13,600$ & $\$ 14,700$ & $\$ 16,000$ \\
\hline \multicolumn{4}{|l|}{ Labor force participation: } \\
\hline Working, full time & $53.7 \%$ & $62.5 \%$ & $66.0 \%$ \\
\hline Working, part time & 8.8 & 4.3 & 2.0 \\
\hline Unemployed & 11.9 & 15.0 & 12.4 \\
\hline Not in labor force & 25.6 & 18.3 & 18.8 \\
\hline \multicolumn{4}{|l|}{ Housing Tenure: } \\
\hline Owner & $4.4 \%$ & $11.7 \%$ & $14.7 \%$ \\
\hline Renter & 95.6 & 88.3 & 85.3 \\
\hline \multicolumn{4}{|l|}{ Net Worth: } \\
\hline$-\$ 1$ to $-\$ 4,999$ & $81.6 \%$ & $67.1 \%$ & $70.4 \%$ \\
\hline$-\$ 5,000$ to $-\$ 9,999$ & 10.6 & 20.5 & 16.5 \\
\hline$-\$ 10,000$ to $-\$ 14,999$ & 3.2 & 3.9 & 4.8 \\
\hline$-\$ 15,000$ to $-\$ 19,999$ & 1.4 & 5.6 & 2.2 \\
\hline$-\$ 20,000$ or less & 3.2 & 3.9 & 4.8 \\
\hline Median & $-\$ 1,500$ & $-\$ 2,300$ & $-\$ 2,300$ \\
\hline \multicolumn{4}{|l|}{ Assets: } \\
\hline Less than $\$ 5,000$ & $73.3 \%$ & $61.4 \%$ & $58.8 \%$ \\
\hline$\$ 5,000$ to $\$ 9,999$ & 13.6 & 17.9 & 17.1 \\
\hline$\$ 10,000$ to $\$ 14,999$ & 4.4 & 8.3 & 7.9 \\
\hline$\$ 15,000$ or more & 8.6 & 12.5 & 16.2 \\
\hline Median & $\$ 1,500$ & $\$ 2,400$ & $\$ 3,400$ \\
\hline \multicolumn{4}{|l|}{ Liabilities: } \\
\hline Less than $\$ 5,000$ & $57.0 \%$ & $42.3 \%$ & $40.1 \%$ \\
\hline$\$ 5,000$ to $\$ 9,999$ & 17.2 & 17.6 & 16.8 \\
\hline$\$ 10,000$ to $\$ 14,999$ & 8.5 & 11.5 & 18.0 \\
\hline$\$ 15,000$ or more & 17.4 & 28.6 & 25.1 \\
\hline Median & $\$ 3,700$ & $\$ 6,700$ & $\$ 7,900$ \\
\hline
\end{tabular}

30 increased from less than 40 percent in 1970 to more than 50 percent in 1980. As the inflation rate came down sharply in the early 1980s, home ownership was no longer viewed as essential, and the rate came back down to about 40 percent over the decade. As a consequence, younger households built wealth more slowly in the 1980s.

These phenomena appear in the SCF. The home ownership rate for households headed by persons in their 30s was about five percentage points higher in 1983 than in 1992. Among those owners, home equity was about $\$ 8,000$ or 19 percent higher in the earlier year and constituted a larger share of their portfolio.

Figure 2 shows the same median wealth information for households by cohort. Wealth clearly increases as people age, until they start to reach the retirement years. Households with heads aged about 58 to 63 in 1983 experienced a decline in wealth during the next six years, and households with heads aged about 53 to 58 in 1983 experienced a decline during the next nine years. These patterns are surely related to retirement. Households with heads in their 70s in 1983 also drew down their wealth over time.

In contrast, households with younger heads built wealth rapidly as they aged, and were consistently richer in 1992 than in 1983, even after the recession.

A comparison of the two figures indicates that the households with the youngest heads (those in their 20s in 1983) experienced an increase in wealth, but did not reach the level that the cohort just above them had enjoyed when the latter were in their $30 \mathrm{~s}$.

Age probably affects household wealth by composition. Married couples without children living at home are typically older than married couples with children, and they usually have the expenses of child-rearing and college tuition behind them. Single women with children are consistently the poorest group, by a very wide margin. The typical woman in this group has next to nothing, and the position of the group did not improve over the cycle. More positively, there appears to have been a remarkable improvement in the wealth of black and Hispanic households during the recessionary period. 


\section{CONCLUSION}

Concern over the concentration of wealth should be tempered by the apparent fact that "the rich" are a changing group, even over rather short periods, and by the fact that they are not coupon clippers, but entrepreneurs. Economists, journalists, and even business men and women seem to think first of stocks when discussing wealth, in my experience, but publicly traded stock is a minor share of wealth for rich people as a whole, and a diminishing share over the 1983-92 period.

The SCF is not a longitudinal survey and therefore the changing composition of the richest 1 percent must be inferred from its reported asset holdings. Independent evidence of household mobility up and down the wealth distribution has recently been reported by Hurst, Luoh, and Stafford (1996), although their work does not specifically support the findings in this article because their data omit the top few percent of the wealth distribution. Clearly, there remains a need for further research into the dynamics of wealth.

\section{REFERENCES}

Avery, Robert B., and Gregory E. Elliehausen. "Financial Characteristics of High-Income Families," Federal Reserve Bulletin (March 1986), pp. 163-77.

, and Arthur B. Kennickell. "Measuring Wealth with Survey Data: An Evaluation of the 1983 Sunvey of Consumer Finances," Review of Income and Wealth (December 1988), pp. 339-69.

Glenn B. Canner, and Thomas A. Gustafson.

"Survey of Consumer Finances, 1983," Federal Reserve Bulletin

(September 1984), pp. 679-92.

Hurst, Erik, Ming Ching Luoh, and Frank P. Stafford. "Wealth Dynamics of American Families, 1984-1994," Working Paper, August 12, 1996.

Kennickell, Arthur B., and Janice Shack-Marquez. "Changes in Family Finances from 1983 to 1989: Evidence from the Survey of Consumer Finances," Federal Reserve Bulletin (January 1992), pp.1-18. and Martha Starr-McCluer. "Changes in Family Finances from 1989 to 1992: Evidence from the Survey of Consumer Finances," Federal Reserve Bulletin (October 1994), pp. $861-82$.

Stanley, Thomas J., and William B. Danko. The Millionaire Next Door Marietta, Ga.: Longstreet Press, 1996.

\section{Table 9}

\section{Median Net Worth by Demographic Category \\ (in thousands of 1992 dollars)}

\begin{tabular}{|c|c|c|c|}
\hline & 1983 & 1989 & 1992 \\
\hline \multicolumn{4}{|c|}{ Age of household head: } \\
\hline Under 25 & $\$ 3.6$ & $\$ 2.4$ & $\$ 3.5$ \\
\hline $25-34$ & 16.2 & 10.7 & 14.2 \\
\hline $35-44$ & 59.1 & 59.8 & 44.7 \\
\hline $45-54$ & 79.3 & 103.0 & 72.9 \\
\hline $55-64$ & 95.6 & 108.5 & 110.6 \\
\hline $65-74$ & 86.5 & 90.8 & 95.8 \\
\hline $75+$ & 56.4 & 81.9 & 87.0 \\
\hline
\end{tabular}

Household composition:

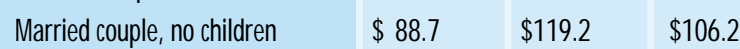

\begin{tabular}{|l|l|l|l|}
\hline Married couple, children & 53.7 & 62.2 & 48.6 \\
\hline
\end{tabular}

\begin{tabular}{|l|l|l|l|}
\hline Single male, no children & 12.1 & 19.1 & 27.9 \\
\hline
\end{tabular}

\begin{tabular}{|l|l|l|l|}
\hline Single male, children & 21.9 & 36.5 & 7.4
\end{tabular}

\begin{tabular}{|l|l|l|l|}
\hline Single female, no children & 28.8 & 32.5 & 35.0 \\
\hline
\end{tabular}

\begin{tabular}{|l|l|l|l|l|l|l|}
\hline Single female, children & 4.8 & 1.2 & 3.0 \\
\hline
\end{tabular}

Race/ ethnicity of household head:

\begin{tabular}{|l|l|r|r|}
\hline White & N.C. & $\$ 80.7$ & $\$ 67.2$ \\
\hline Black & N.C. & 4.9 & 14.3 \\
\hline Hispanic* & N.C. & 3.4 & 8.6 \\
\hline Other** & N.C. & 41.5 & 40.9 \\
\hline
\end{tabular}

N.C.: Not calculated because of inconsistency with identification procedures used in later surveys.

* Hispanic Americans are counted as a separate group.

** Asian and Pacific Islander, and American Indian/ Alaskan native

U.S. Bureau of the Census. "Statistical Brief: Who Owns the Nation's Rental Properties?" SB96-1, March 1996.

Weicher, John C. "Changes in the Distribution of Wealth: Increasing Inequality?" this Review (January/ February 1995), pp. 5-23.

\footnotetext{
"Wealth and its Distribution, 1983-1992: Secular Growth, Cydical Stability," this Review (January/ February 1997), pp. 3-23.
}

Wolff, Edward N. Top Heawy, New York: Twentieth Century Fund, 1995. 